\title{
Forms of phosphorus of vermicompost produced from leaf compost and sheep dung enriched with rock phosphate
}

\author{
Ebrahim Adhami · Sara Hosseini · Hamidreza Owliaie
}

Received: 17 July 2013/ Accepted: 28 June 2014/Published online: 23 July 2014

(C) The Author(s) 2014. This article is published with open access at Springerlink.com

\begin{abstract}
Abstarct
Introduction Vermicomposting could increase nutrients availability including phosphorus. During vermicomposting, a decomposition of organic substrates leads to the production of several organic acids, such as malonic, fumaric, succinic acids. Microorganisms both in the intestinal organ of the worms and the organic waste have the ability to convert insoluble $\mathrm{P}$ into soluble forms. Little information exists about the effects of vermicomposting on rock phosphate (RP) solubilization. Present study was conducted to evaluate the solubilization of powdered RP during vermicomposting.

Results Vermicomposting and RP application increased $\mathrm{NaHCO}_{3}-\mathrm{P}_{\mathrm{i}}$. Rock phosphate application in vermicomposting significantly increased $\mathrm{NaHCO}_{3}-\mathrm{P}_{\mathrm{o}}$. Vermicomposting significantly increased $\mathrm{NaOH}-\mathrm{P}_{i}$ in all of the treatments. RP application and vermicomposting increased $\mathrm{HCl}-\mathrm{P}_{\mathrm{i}}$ in both organic sources. Generally, vermicomposting increased $\mathrm{HCl}-\mathrm{P}_{\mathrm{o}}$. Vermicomposting decreased $\mathrm{pH}$ but its effect was more evident in the presence of RP. Vermicomposting increased EC in both organic sources.

Conclusion Present study showed that vermicomposting helps to enhance the transformation of $\mathrm{P}$ from RP into various organic or inorganic $P$ forms, which would be readily or moderately available, thus, increase the availability of $\mathrm{P}$ from both RPs.
\end{abstract}

Keywords Eisenia fetida $\cdot \mathrm{NaHCO}_{3}-\mathrm{P} \cdot \mathrm{NaOH}-\mathrm{P} \cdot \mathrm{HCl}-\mathrm{P}$

E. Adhami $(\bowtie) \cdot$ S. Hosseini $\cdot$ H. Owliaie

College of Agriculture, Yasouj University, Yasouj, Iran

e-mail: eadhami@gmail.com

\section{Introduction}

The high cost of chemical $\mathrm{P}$ fertilizer production has generated considerable interest toward direct utilization of rock phosphate in some countries as well as Iran (Besharati et al. 2001). Most of the RPs are reasonably suitable for direct use in acid soils, but has not given satisfactory results in neutral to alkaline soils (Narayanasamy and Biswas 1998). Some methods for improving the efficacy of RP are mixing with elemental sulfur (Mohammady Aria et al. 2010), partial acidulation with nominal amount of acid, dry compaction with water-soluble $\mathrm{P}$ fertilizers (Biswas and Narayanasamy 2006) and mixing RP with organic residues, such as compost, manure, and vermicompost (Odongo et al. 2007; Biswas and Narayanasamy 2006).

Vermicompost is an efficient tool to manage the utilization of organic residues (Garg et al. 2006) and increase nutrients availability including phosphorus (Ghosh et al. 1999; Venkatesh and Eevera 2008). During vermicomposting, a decomposition of organic substrates leads to the production of several organic acids such as malonic, fumaric, succinic acids (Epstein 1997), and soluble humic molecules (Atiyeh et al. 2002). Both assimilation and mineralization of phosphorus are microorganisms mediated processes and application of vermicompost increases the rates of these two processes in soil.

Previous studies have revealed the beneficial effect of mixing rock phosphate with vermicompost. Pramanik et al. (2009) repoted that vermicomposts increased (13-26\%) available $\mathrm{P}$ of soil after 90 days of incubation. Available $\mathrm{P}$ content of rock phosphate-treated soils increased steadily up to 45 days of incubation, but thereafter it gradually decreased forming a parabolic shaped rate curve for $\mathrm{P}$ transformation. Initial decrease in $\mathrm{P}$ content in vermicompost-treated soils could be avoided or minimized by 
Table 1 Chemical properties of raw organic materials

\begin{tabular}{llllllll}
\hline Organic matter & $\begin{array}{l}\mathrm{NaHCO}_{3}-\mathrm{P}_{\mathrm{i}} \\
\left(\mathrm{mg} \mathrm{kg}^{-1}\right)\end{array}$ & $\mathrm{NaHCO}_{3}-\mathrm{P}_{\mathrm{o}}$ & $\begin{array}{l}\mathrm{P}_{\mathrm{t}}^{*} \\
(\%)\end{array}$ & O.C & $\mathrm{C}: \mathrm{P}$ & $\begin{array}{l}\mathrm{EC} \\
\left.(\mathrm{dS} \mathrm{m})^{-1}\right)\end{array}$ & $\begin{array}{l}\mathrm{pH} \\
(1: 2.5)\end{array}$ \\
\hline Sheep dung & 291 & 45.5 & 0.35 & 38.9 & 111 & 8.7 & 8.5 \\
Leaf compost & 388 & 32.4 & 0.28 & 21.2 & 76 & 1.02 & 80 \\
\hline
\end{tabular}

* $\mathrm{P}_{\mathrm{t}}(\%)$; O.C; EC; WHC represent total phosphorus; organic carbon; electrical conductivity; and water-holding capacity, respectively

application of rock phosphate in combination with vermicomposts (Pramanik et al. 2009). Mohammady Aria et al. (2010) observed that vermicompost had a significant effect on the water-soluble phosphates of hard phosphate rock.

Many studies have been conducted about the changes of biochemical properties and nutrients (including P) availability during vermicomposting, but little information exists about the effects of vermicomposting on RP solubilization, and various organic or inorganic $\mathrm{P}$ fractions. Present study was conducted to evaluate the solubilization of RP from Esfordi plant during vermicomposting and the influence of $\mathrm{RP}$ on $\mathrm{pH}$ and $\mathrm{EC}$ of the produced vermicompost.

\section{Methods and materials}

Preparation of materials

Two organic matters (leaf compost and sheep dung) were used in the present study. Chemical characteristics of organic sources including $\mathrm{pH}$ and electrical conductivity (EC) in a 1:2.5 water mixture, loss on ignition by heating at $550{ }^{\circ} \mathrm{C}$ for $4 \mathrm{~h}$, organic and inorganic phosphorus soluble in bicarbonate $\left(\mathrm{NaHCO}_{3}-\mathrm{P}_{\mathrm{o}}\right.$ and $\left.\mathrm{NaHCO}_{3}-\mathrm{P}_{\mathrm{i}}\right)$, total $\mathrm{P}$ after dry ashing (Kou 1996) and C:P ratio were determined. Water-holding capacity was determined following $24 \mathrm{~h}$ drainage of saturated organic materials (Table 1). Moisture content of $\mathrm{OM}$ was determined by drying a specified weight under $70{ }^{\circ} \mathrm{C}$ for $48 \mathrm{~h}$.

Experimental treatments consisted of a factorial combination of organic matter (compost or sheep dung), powder rock phosphate (Zero, $6 \%$ raw RP, and $2 \%$ modified RP) and earthworms of Eisenia fetida (zero or 20 adult individuals per pot) with three replications in a completely randomized design. Powder of raw and modified RP was obtained from Esfordi phosphate Plant. The modification procedure contains leaching and floatation and includes no acid treatment, thereupon the water-soluble P of both RP was negligible. Physico-chemical characteristics of phosphate materials are presented in Table 2 .

Five hundred $\mathrm{g}$ of calculated dry organic matter (based on moisture content) was placed in a suitable plastic bag with appropriate amount of RP. After thoroughly mixing,
Table 2 Chemical characteristics of rock phosphate

\begin{tabular}{llllll}
\hline Substance & $\begin{array}{l}\text { Water- } \\
\text { soluble } \mathrm{P}\end{array}$ & $\begin{array}{l}\text { Total } \\
\mathrm{P}_{2} \mathrm{O}_{5} \\
\%\end{array}$ & $\mathrm{SiO}_{2}$ & $\mathrm{Fe}_{2} \mathrm{O}_{3}$ & $\mathrm{Cd}$ \\
\hline Raw & $\begin{array}{c}\text { Not } \\
\text { detectable }\end{array}$ & $12 \pm 1$ & $1.2 \pm 0.5$ & $1.4 \pm 0.7$ & $3 \pm 2$ \\
Modified & $\begin{array}{c}\text { Not } \\
\text { detectable }\end{array}$ & $37 \pm 1$ & $3.50 \pm 1$ & $3.5 \pm 1$ & $10 \pm 5$ \\
& & & & \\
\hline
\end{tabular}

materials were transferred into suitable plastic pots, which contained a three $\mathrm{cm}$ layer of rinsed sand beneath. Ten pairs of earthworm species Eisenia fetida were placed on each pot and sprayed gently with water. Pots were kept at $70 \%$ water-holding capacity by weighing each 3 days under lab temperatures. After 2 months organic materials was separated by sieving at suitable moisture content and allowed to air dry.

Chemical analyses

Inorganic and organic $\mathrm{P}$ fractions was extracted separately with sodium bicarbonate $0.5 \mathrm{M} \mathrm{pH} 8.5$ after $30 \mathrm{~min}$ shaking $\left(\mathrm{NaHCO}_{3}-\mathrm{P}_{\mathrm{i}}\right.$ and $\mathrm{NaHCO}_{3}-\mathrm{P}_{\mathrm{o}}$, respectively), sodium hydroxide $0.1 \mathrm{M}$ after $2 \mathrm{~h}$ shaking $\left(\mathrm{NaOH}-\mathrm{P}_{\mathrm{i}}\right.$ and $\mathrm{NaOH}-\mathrm{P}_{\mathrm{o}}$, respectively), hydrochloric acid $0.5 \mathrm{M}$ after $2 \mathrm{~h}$ shaking ( $\mathrm{HCl}-\mathrm{P}_{\mathrm{i}}$ and $\mathrm{HCl}-\mathrm{P}_{\mathrm{o}}$, respectively). Reactive $\mathrm{P}$ in the supernatant was determined using the ascorbic acid method at $882 \mathrm{~nm}$ (Murphy and Riley 1962) and total P of the supernatants was determined after digestion of a suitable aliquot as described by Fan et al. (1999). Organic P was calculated as the difference between total and reactive $\mathrm{P}$ in the extracts. $\mathrm{pH}$ and electrical conductivity (EC) were determined in a 1:2.5 OM:water mixture.

Statistical analyses conducted using MSTATC software.

\section{Results and discussion}

Phosphorus fractions

Vermicomposting increased $\mathrm{NaHCO}_{3}-\mathrm{P}_{\mathrm{i}}$ from $145 \mathrm{mg} \mathrm{kg}^{-1}$ in the control of sheep dung to $215 \mathrm{mg} \mathrm{kg}^{-1}$. Application of 6 and $2 \%$ of raw and modified RP increased 
Table 3 Changes in the $\mathrm{NaHCO}_{3}$ extractable $\mathrm{P}\left(\mathrm{mg} \mathrm{kg}^{-1}\right)$ of sheep dung and leaf compost $\left(\mathrm{LSD}_{0.05}\right.$ for $\mathrm{NaHCO}_{3}-\mathrm{P}_{\mathrm{i}}=7.37$ and for $\left.\mathrm{NaHCO}_{3}-\mathrm{P}_{\mathrm{o}}=7.91\right)$

\begin{tabular}{|c|c|c|c|}
\hline & \multicolumn{2}{|c|}{ Vermicomposting } & \multirow[t]{2}{*}{ Mear } \\
\hline & - & + & \\
\hline \multicolumn{4}{|l|}{$\mathrm{NaHCO}_{3}-\mathrm{P}_{\mathrm{i}}$} \\
\hline \multicolumn{4}{|l|}{ Sheep dung } \\
\hline 0 & 145 & 215 & 180 \\
\hline $6 \%$ Raw RP & 220 & 227 & 223 \\
\hline $2 \%$ modified RP & 228 & 237 & 232 \\
\hline Mean & 197 & 226 & 211 \\
\hline \multicolumn{4}{|l|}{ Compost } \\
\hline 0 & 139 & 203 & 171 \\
\hline $6 \%$ Raw RP & 181 & 226 & 203 \\
\hline $2 \%$ modified RP & 199 & 230 & 214 \\
\hline Mean & 173 & 219 & 196 \\
\hline \multicolumn{4}{|l|}{$\mathrm{NaHCO}_{3}-\mathrm{P}_{\mathrm{o}}$} \\
\hline \multicolumn{4}{|l|}{ Sheep dung } \\
\hline 0 & 84 & 131 & 107 \\
\hline $6 \%$ Raw RP & 86 & 123 & 104 \\
\hline $2 \%$ modified RP & 96 & 150 & 123 \\
\hline Mean & 88.7 & 134 & 111 \\
\hline \multicolumn{4}{|l|}{ Compost } \\
\hline 0 & 71 & 78 & 74.5 \\
\hline $6 \%$ Raw RP & 108 & 115 & 111 \\
\hline $2 \%$ modified RP & 119 & 131 & 125 \\
\hline Mean & 99.3 & 108 & 103 \\
\hline
\end{tabular}

this fraction to 220 and $228 \mathrm{mg} \mathrm{kg}^{-1}$ but vermicomposting did not considerably change it in the presence of RP. Similar to sheep dung, RP application and vermicomposting increased $\mathrm{NaHCO}_{3}-\mathrm{P}_{\mathrm{i}}$ of leaf compost. In average, vermicomposting increased $\mathrm{NaHCO}_{3}-\mathrm{P}_{\mathrm{o}}$ by $35 \%$ and the trend was consistent in all of the treatments. Rock phosphate application had a little effect on $\mathrm{NaHCO}_{3}-\mathrm{P}_{\mathrm{o}}$ in the absence of vermicomposting but when vermicomposted significantly increased $\mathrm{NaHCO}_{3}-\mathrm{P}_{\mathrm{o}}$, i.e., vermicomposting of $2 \%$ modified RP treatments caused 54 and $12 \mathrm{mg} \mathrm{kg}^{-1}$ increase of $\mathrm{NaHCO}_{3}-\mathrm{P}_{\mathrm{o}}$ in sheep dung and leaf compost, respectively (Table 3). Among different $\mathrm{P}$ fractions, bicarbonate extractable inorganic and organic $\mathrm{P}\left(\mathrm{NaHCO}_{3}-\mathrm{P}_{\mathrm{i}}\right.$ and $\mathrm{NaHCO}_{3}-\mathrm{P}_{\mathrm{o}}$ ) collectively form the bioavailable or labile $\mathrm{P}$ in the soil (Sui et al. 1999). Previous studies have revealed the increase of inorganic available $\mathrm{P}$ by vermicomposting. Ghosh et al. (1999) found that saloid-bound P was considerably higher in the earthworm-treated wastes than in the wastes without earthworms, showing that inoculation of earthworms in wastes was useful in increasing the amount of such loosely held and, thereby, easily accessible, forms of $\mathrm{P}$ in the organic wastes. Pal Vig et al. (2001) reported that the total available $\mathrm{P}$ was significantly higher after
Table 4 Changes in the $\mathrm{NaOH}$ extractable $\mathrm{P}\left(\mathrm{mg} \mathrm{kg}^{-1}\right)$ of sheep dung and leaf $\left(\mathrm{LSD}_{0.05}\right.$ for $\mathrm{NaOH}-\mathrm{P}_{\mathrm{i}}=3.80$ and for $\mathrm{NaOH}-$ $\mathrm{P}_{\mathrm{o}}=10.3$ )

\begin{tabular}{|c|c|c|c|}
\hline & \multicolumn{2}{|c|}{ Vermicomposting } & \multirow[t]{2}{*}{ Mean } \\
\hline & - & + & \\
\hline \multicolumn{4}{|l|}{$\mathrm{NaOH}-\mathrm{P}_{\mathrm{i}}$} \\
\hline \multicolumn{4}{|l|}{ Sheep dung } \\
\hline 0 & 31.3 & 49.9 & 40.6 \\
\hline $6 \%$ Raw RP & 39.4 & 59.1 & 49.6 \\
\hline $2 \%$ modified RP & 44.4 & 53.6 & 49 \\
\hline Mean & 38.3 & 54.2 & 46.3 \\
\hline \multicolumn{4}{|l|}{ Compost } \\
\hline 0 & 10.5 & 29.8 & 20.1 \\
\hline $6 \%$ Raw RP & 13.6 & 33.8 & 23.7 \\
\hline $2 \%$ modified RP & 15.7 & 41.9 & 28.8 \\
\hline Mean & 13.3 & 35.1 & 24.2 \\
\hline \multicolumn{4}{|l|}{$\mathrm{NaOH}-\mathrm{P}_{\mathrm{o}}$} \\
\hline \multicolumn{4}{|l|}{ Sheep dung } \\
\hline 0 & 69.5 & 144 & 106 \\
\hline $6 \%$ Raw RP & 72.5 & 150 & 111 \\
\hline $2 \%$ modified RP & 100 & 192 & 146 \\
\hline Mean & 80.7 & 162 & 121 \\
\hline \multicolumn{4}{|l|}{ Compost } \\
\hline 0 & 42.8 & 83.7 & 63.2 \\
\hline $6 \%$ Raw RP & 57.2 & 105 & 81.1 \\
\hline $2 \%$ modified RP & 52.2 & 109 & 80.6 \\
\hline Mean & 50.7 & 99.2 & 74.9 \\
\hline
\end{tabular}

vermicomposting than the initial one. In the present study, it was observed that in addition to easily available $P_{i}$, easily available $\mathrm{P}_{\mathrm{o}}$ will be enhanced by vermicomposting.

Sodium hydroxide extractable $\mathrm{P}_{\mathrm{i}}\left(\mathrm{NaOH}-\mathrm{P}_{\mathrm{i}}\right)$ in sheep dung was almost threefold of that in leaf compost (Table 4). Sodium hydroxide $(\mathrm{NaOH})$ is mainly used to remove inorganic $\mathrm{Al}$ and $\mathrm{Fe}-\mathrm{P}$ fraction in soils (Adhami et al. 2006) but when used for OM the origin of inorganic $P$ is undefined and in this case it might extract acidic phosphatase. Rock phosphate application had a little effect on this fraction (Table 4), while vermicomposting significantly increased it in all of the treatments. In average, vermicomposting caused $75 \%$ increase of $\mathrm{NaOH}-\mathrm{P}_{\mathrm{i}}$, but the effects of the treatments were more evident on $\mathrm{NaOH}-$ $\mathrm{P}_{\mathrm{o}}$. In average vermicomposting cuased about $100 \%$ increase of $\mathrm{NaOH}-\mathrm{P}_{\mathrm{o}}$. Application of $2 \%$ modified $\mathrm{RP}$ increased $\mathrm{NaOH}-\mathrm{P}_{\mathrm{o}}$ by $30.5 \mathrm{mg} \mathrm{kg}{ }^{-1}$ in sheep dung but the increase was less for leaf compost (Table 4). According to Cross and Schlesinger (1995), soil organic C controls variability of $\mathrm{NaOH}-\mathrm{P}_{\mathrm{o}}$ pool in the soils. The $\mathrm{NaOH}$ extracts $\mathrm{P}$ mainly from organic components and some amorphous aluminum-containing compounds in soil (Cassagne et al. 2000) that is; the $\mathrm{P}$ associated with humic acids 
Table 5 Changes in the $\mathrm{HCl}$ extractable $\mathrm{P}\left(\mathrm{mg} \mathrm{kg}^{-1}\right)$ of sheep dung and leaf compost $\left(\mathrm{LSD}_{0.05}\right.$ for $\mathrm{HCl}-\mathrm{P}_{\mathrm{i}}=41.75$ and for $\mathrm{HCl}-$ $\left.\mathrm{P}_{\mathrm{o}}=80.17\right)$

\begin{tabular}{|c|c|c|c|}
\hline & \multicolumn{2}{|c|}{ Vermicomposting } & \multirow[t]{2}{*}{ Mear } \\
\hline & - & + & \\
\hline \multicolumn{4}{|l|}{$\mathrm{HCl}-\mathrm{P}_{\mathrm{i}}$} \\
\hline \multicolumn{4}{|l|}{ Sheep dung } \\
\hline 0 & 888 & 1,233 & 1,060 \\
\hline $6 \%$ Raw RP & 991 & 1,401 & 1,196 \\
\hline $2 \%$ modified RP & 1,097 & 1,476 & 1,286 \\
\hline Mean & 992 & 1,370 & 1,180 \\
\hline \multicolumn{4}{|l|}{ Leaf Compost } \\
\hline 0 & 860 & 1,265 & 1,062 \\
\hline $6 \%$ Raw RP & 971 & 1,683 & 1,377 \\
\hline $2 \%$ modified RP & 1,148 & 1,746 & 1,447 \\
\hline Mean & 1,026 & 1,564 & 1,295 \\
\hline \multicolumn{4}{|l|}{$\mathrm{HCl}-\mathrm{P}_{\mathrm{o}}$} \\
\hline \multicolumn{4}{|l|}{ Sheep dung } \\
\hline 0 & 960 & 1,016 & 988 \\
\hline $6 \%$ Raw RP & 989 & 1,207 & 1,098 \\
\hline $2 \%$ modified RP & 1,048 & 1,293 & 1,170 \\
\hline Mean & 999 & 1,172 & 1,085 \\
\hline \multicolumn{4}{|l|}{ Leaf Compost } \\
\hline 0 & 659 & 869 & 764 \\
\hline $6 \%$ Raw RP & 878 & 748 & 813 \\
\hline $2 \%$ modified RP & 934 & 867 & 900 \\
\hline Mean & 823 & 828 & 825 \\
\hline
\end{tabular}

or chemisorbed to the surfaces of $\mathrm{Fe}$ and $\mathrm{Al}$ compounds (Schoenau et al. 1989). The products of microbial decomposition of organic materials might solubilize some of the sorbed or recalcitrant $\mathrm{P}$ in soil causing an increase in organic $\mathrm{P}$ associated with the humic substances (Reddy et al. 2005). Organic $\mathrm{P}$ extracted with $\mathrm{NaOH}(\mathrm{NaOH}-\mathrm{P})$ is introduced as stable organic $\mathrm{P}$ compounds (Fan et al. 1999), though this fraction is not readily available for plants, but the high resistance of this fraction could maintain $P$ availability in an intermediate period. Nonlabile $\mathrm{P}$ fractions are thought to be tightly bound to soil particles, and unavailable to plants. The nonoccluded phosphorus, including phosphorus that is extracted with $\mathrm{NaOH}$, is considered to be biologically available over an intermediate time scale (Cross and Schlesinger 1995).

Inorganic $\mathrm{P}$ extracted with $\mathrm{HCl}$ is attributed to the highly stable $\mathrm{Ca}-\mathrm{P}$ compounds (i.e., various apatite compounds). This fraction was the highest among various $\mathrm{P}$ fractions in all of the treatments and showed the highest increase with RP application. Rock phosphate application increased inorganic $\mathrm{P}$ extracted with $\mathrm{HCl}(\mathrm{HCl}-\mathrm{Pi})$ in both organic sources. The increase of $\mathrm{HCl}-\mathrm{Pi}$ by the RP addition was almost equal for both organic sources in the absence of

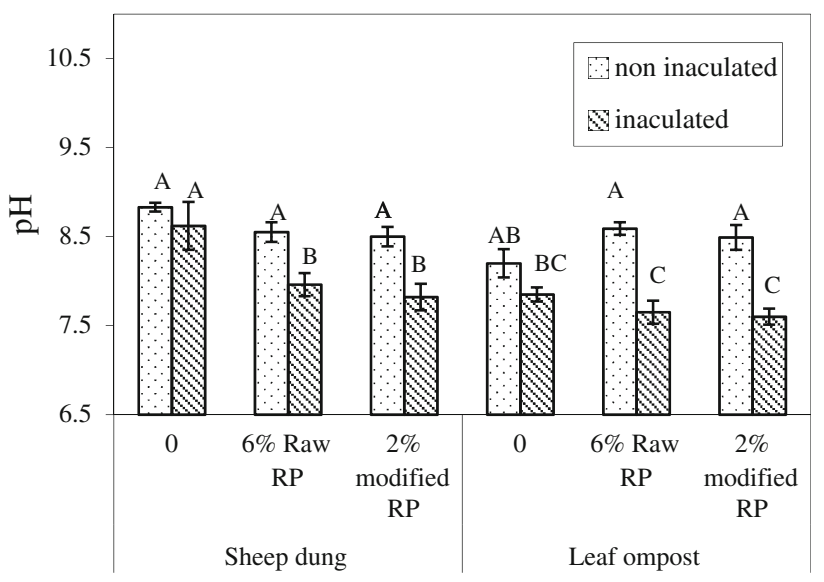

Fig. 1 Changes in the $\mathrm{pH}$ value of sheep dung and leaf compost in presence and absence of Eisenia fetida. Means within the same organic sources followed by the same letter are not significantly different at $P<0.01$

vermicomposting. In average, $\mathrm{HCl}-\mathrm{Pi}$ increased by 209 and $288 \mathrm{mg} \mathrm{kg}^{-1}$ in $2 \%$ modified RP in sheep dung and leaf compost, respectively. In addition, vermicomposting was associated with a great increase of $\mathrm{HCl}-\mathrm{Pi}$ in both organic sources. On the other hand, vermicomposting in the presence of RP considerably increased HCl-Pi (Table 5). Vermicomposting of leaf compost increased $\mathrm{HCl}-\mathrm{Pi}$ around $405 \mathrm{mg} \mathrm{kg}^{-1}$ but in the presence of RP the increase was about $598 \mathrm{mg} \mathrm{kg}^{-1}$. In average, vermicomposting increased $\mathrm{HCl}-\mathrm{Pi}$ by $450 \mathrm{mg} \mathrm{kg}{ }^{-1}$. $\mathrm{HCl}-\mathrm{P}_{\mathrm{o}}$ increased from $960 \mathrm{mg} \mathrm{kg}^{-1}$ in the control of sheep dung to $1,048 \mathrm{mg} \mathrm{kg}^{-1}$ by the addition of $2 \%$ modified RP while the increase was higher in the leaf compost and caused $275 \mathrm{mg} \mathrm{kg}^{-1}$ increase of HCl-P. $\mathrm{P}_{\mathrm{o}}$. Generally, vermicomposting increased $\mathrm{HCl}-\mathrm{P}_{\mathrm{o}}$ in sheep dung and the application of RP caused higher increase of $\mathrm{HCl}-\mathrm{P}_{\mathrm{o}}$; the trend, which was not observed for leaf compost (Table 5). The HCl- $\mathrm{P}_{\mathrm{o}}$ is considered to be derived from particulate organic matter which is unavailable in its current form but may become bioavailable after microbial decomposition (Tiessen and Moir 1993).

When organic matter are passed through gut of earthworms, some phosphorous being converted with more availability to plants (Lee 1985), which might be the cause for the increase in available phosphorous content of the vermicompost in the present study. The increase in phosphorus is due to both direct action of worm gut enzymes and indirectly by stimulation of the microflora (Lee 1985).

$\mathrm{pH}$ and $\mathrm{EC}$

Changes of $\mathrm{pH}$ by $\mathrm{RP}$ application was low and not consistent for the both organic sources (i.e., RP application decreased $\mathrm{pH}$ of sheep dung slightly but not in leaf compost). Vermicomposting decreased $\mathrm{pH}$ but its effect was 


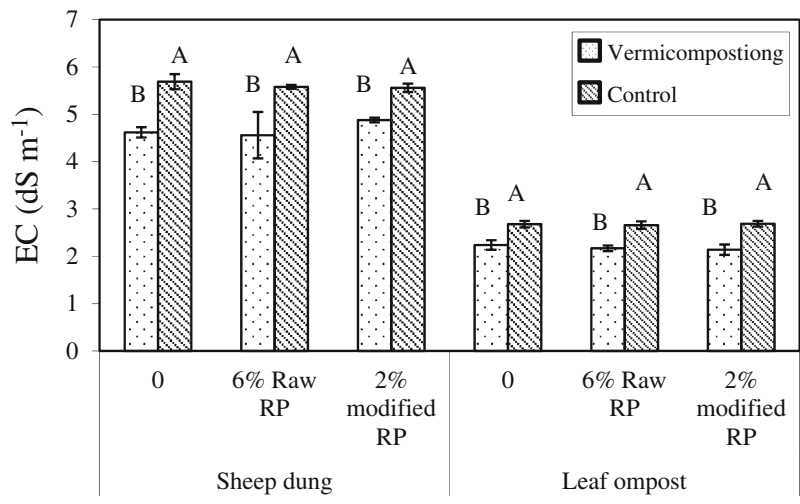

Fig. 2 Changes in the EC ( $\mathrm{dS} \mathrm{m}^{-1}$ ) value of sheep dung and leaf compost in presence and absence of Eisenia fetida. Means within the same organic sources followed by the same letter are not significantly different at $P<0.01$

more pronounced in the presence of RP. Vermicomposting decreased $\mathrm{pH}$ of sheep dung from 8.82 in control to 8.62 in the absence of RP, but decreased to 7.96 and 7.82 in the presence of 6 and $2 \%$ of raw and modified RP, respectively. Similar results were observed in leaf compost (Fig. 1). This is in accordance with the results of Atiyeh et al. (2000) and Venkatesh and Eevera (2008) and Raphael and Velmourougane (2011). pH decrease may be due to the accumulation of organic acids from microbial metabolism or from the production of fulvic and humic acids during decomposition (Albanell et al. 1988).

Vermicomposting caused the highest changes of EC in both organic sources and its effect seemed to be independent of presence or type of RP. In average, the EC of sheep dung and leaf compost were 4.69 and $2.18 \mathrm{dS} \mathrm{m}^{-1}$ and increased to 5.61 and 2.68 by vermicomposting, respectively (Fig. 2). RP application or type did not cause considerable and consistent changes of EC. The electrical conductivity reflects the salinity of an organic amendment. The increase of EC during vermicomposting is also reported by others (Venkatesh and Eevera 2008; Pal Vig et al. 2001). The increase in EC could be due to loss of organic matter and release of different mineral salts in available forms, such as phosphate, ammonium, potassium, etc. (Venkatesh and Eevera 2008; Pal Vig et al. 2001; Kaviraj and Sharma 2003).

\section{Conclusion}

Present study showed that vermicomposting helps to enhance the transformation of $\mathrm{P}$ from $\mathrm{RP}$ into various organic or inorganic $\mathrm{P}$ forms, which would be readily or moderately available. Thus, increase the availability of $\mathrm{P}$ from both RPs. RPs application helped the decrease of $\mathrm{pH}$ through vermicomposting which would cause higher nutrients availability. EC increased by vermicomposting but RP addition had a little effect on it.

Open Access This article is distributed under the terms of the Creative Commons Attribution License which permits any use, distribution, and reproduction in any medium, provided the original author(s) and the source are credited.

\section{References}

Adhami E, Maftoun M, Ronaghi A, Karimian N, Yasrebi J, Assad MT (2006) Inorganic phosphorus fractionation of highly calcareous soils. Commun Soil Sci Plant Anal 37:1877-1888

Albanell E, Plaixats J, Cabrero T (1988) Chemical changes during vermicomposting (Eisenia fetida) of cow manure mixed with cotton industrial wastes. Biol Fert Soils 6:266-269

Atiyeh RM, Domínguez J, Subler S, Edwards CA (2000) Changes in biochemical properties of cow manure during processing by earthworms (Eisenia andrei, Bouché) and the effects on seedling growth. Pedobiologia 44:709-724

Atiyeh RM, Lee S, Edwards CA, Arancon NQ, Metzger JD (2002) The influence of humic acids derived from earthworm-processed organic wastes on plant growth. Bioresour Technol 84:7-14

Besharati H, Noorgholipour F, Malakouti MJ, Khavazi K, Lotfollahi M, Ardakani MS (2001) Direct application of phosphate rock to Iran calcareous soils. Paper presented at the international meeting on direct application of phosphate rock and related appropriate technology, Kuala Lumpur, 16-20 July, 2001

Biswas DR, Narayanasamy G (1998) Direct and residual effectiveness of partially acidulated P fertilizers in a cowpea-wheat cropping system. J Indian Soc Soil Sci 46:406-411

Biswas DR, Narayanasamy G (2006) Rock phosphate enriched compost: an approach to improve low-grade Indian rock phosphate. Bioresour Technol 97:2243-2251

Cassagne N, Remaury M, Gauquelin T, Fabre A (2000) Forms and profile distribution of soil phosphorus in alpine Inceptisols and Spodosols (Pyrenees, France). Geoderma 95:161-172

Cross AF, Schlesinger WH (1995) A literature review and evaluation of the Hedley fractionation: applications to the biogeochemical cycle of soil phosphorus in natural ecosystems. Geoderma 64:197-214

Epstein E (1997) The Science of composting. Technomic Publishing Co. Inc., Lancaster

Fan Y, Xiong H, Li S (1999) Some improvements of the fractionation method of organic phosphorus in calcareous soils. Geoderma 93:195-206

Garg P, Gupta A, Satya S (2006) Vermicomposting of different types of waste using Eisenia foetida: a comparative study. Bioresour Technol 97:391-395

Ghosh M, Chattopadhyay GN, Baral K (1999) Transformation of phosphorus during vermicomposting. Bioresour Technol 69:149-154

Kaviraj, Sharma S (2003) Municipal solid waste management through vermicomposting employing exotic and local species of earthworms. Bioresour Technol 90:169-173

Lee KE (1985) Earthworms, their ecology and relationships with soil and land use. Academic Press, Sydney

Mohammady Aria M, Lakzian A, Haghnia GH, Berenji AR, Besharati H, Fotovat A (2010) Effect of Thiobacillus, sulfur, and vermicompost on the water-soluble phosphorus of hard rock phosphate. Bioresour Technol 101:551-554

Murphy J, Riley JP (1962) A modified single solution method for determination of phosphate in natural waters. Anal Chim Acta $27: 31-36$ 
Narayanasamy G, Biswas DR (1998) Phosphate rocks of Indiapotentialities and constraints. Fert News 43(21-28):31-32

Odongo NE, Hyoung-Ho K, Choi Hee-chul, Van Straaten P, McBride BW, Romney DL (2007) Improving rock phosphate availability through feeding, mixing and processing with composting manure. Bioresour Technol 98:2911-2918

Pal Vig A, Singh J, Wani SH, Dhaliwa SS (2001) Vermicomposting of tannery sludge mixed with cattle dung into valuable manure using earthworm Eisenia fetida (Savigny). Bioresour Technol 102:7941-7945

Pramanik P, Bhattacharya S, Bhattacharyya P, Banik P (2009) Phosphorous solubilization from rock phosphate in presence of vermicomposts in Aqualfs. Geoderma 152:16-22

Raphael K, Velmourougane K (2011) Chemical and microbiological changes during vermicomposting of coffee pulp using exotic (Eudrilus eugeniae) and native earthworm (Perionyx ceylanesis) species. Biodegradation 22:497-507
Reddy KR, Wetzel RG, Kadlec RH (2005) Biogeochemistry of phosphorus in wetlands. In: Sims JT, Sharpley AN (eds) Phosphorus: agriculture and the environment. Agron. Monogr. 46. ASA, CSSA, and SSSA, Madison WI

Schoenau JJ, Stewart JWB, Bettany JR (1989) Forms and cycling of phosphorus in prairie and boreal forest soils. Biogeochem $8: 223-237$

Sui Y, Thompson ML, Shang C (1999) Fractionation of phosphorus in a Mollisol amended with biosolids. Soil Sci Soc Am J 63:1174-1180

Tiessen H, Moir JO (1993) Characterization of available $\mathrm{P}$ by sequential extraction. In: Carter MR (ed) Soil sampling and methods of analysis. Can Soc Soil Sci, Lewis Publishers, Boca Raton

Venkatesh RM, Eevera T (2008) Mass Reduction and recovery of nutrients through vermicomposting of fly ash. Appl Ecol Environ Res 6:77-84 